\title{
UMA LEITURA DO MITO DE \\ Narciso: as águas profundas de uma sanga gaúcha
}

Raquel Souza

Uma das questóes que mais me instigam diz respeito às autobiografias de poetas, especialmente os de formação modernista. A poesia, desde os primórdios do século $\mathrm{XX}$, teve sua essência ligada à produção ficcional e, assim, abandonou o extravasamento confessional. A escrita autobiográfica surge desse modo, como o "outro" da ficção, porquanto o gênero autobiográfico pressupóe um discurso verídico, ou melhor, uma "ilusão de realidade" mais consistente do que a dos romances autobiográficos ou mesmo a dos romances históricos. Corrobora este caráter "real" das autobiografias o narrador que se confunde com o homem de carne e osso, que responde pelo mesmo nome e que se apresenta como o protagonista dos eventos e sentimentos narrados, propondo, assim, aquilo que chamamos de "pacto autobiográfico" de leitura ${ }^{1}$.

Por outro lado, os conceitos sobre as produçôes do gênero autobiográfico são múltiplos. Talvez seja um tanto enfadonho, para quem se debruça sobre o assunto, recorrer à clássica definiçẫo proposta por Philippe Lejeune; no entanto, é a partir dele que se pensa e repensa o gênero autobiográfico em seus variados matizes, desde as autobiografias até àquilo que se chama de "autoficçâo". Assim, em tempo de lembrar: autobiografia é a narrativa que uma pessoa real faz de sua própria existência, dando a si mesma a posição inequívoca de protagonista ${ }^{3}$. Aliada a esta definição, Lejeune também acrescenta outros condicionantes: narrativa retrospectiva e em prosa. Estes requisitos 
sistematizados em seu clássico estudo sobre o gênero, de 1975, sempre me pareceram muito dogmáticos para tratar de literatura, cuja natureza, sabemos, é marcada por uma intensa movimentação, por uma profunda renovação, por uma necessidade inequívoca de readaptaçôes. É bem verdade que, passados alguns anos da publicação de seu texto paradigmático sobre o assunto, Lejeune buscou uma relativização de seus pressupostos teóricos, admitindo um alargamento das fronteiras que limitavam seus conceitos. Em "El pacto veintecinco años después" (LEJEUNE, 2001), ele admite novos formatos para a palavra autobiográfica, ainda que mantenha sua disposição em asseverar a necessidade do pacto autobiográfico na conduçấo do processo de leitura.

Por isso, prefiro particularmente pensar que a produção autobiográfica alargou sobremaneira seus limites. Tenho trabalhado a partir de conceitos diversos sobre as produções autobiográficas. Daí meu grande interesse focalizado nos poetas modernistas, os quais, na sua grande maioria, produziram textos de matriz autobiográfica (estrito senso) ao lado de poemas igualmente de extrato autobiográfico ${ }^{4}$. Não obstante, quero ressaltar que, para este ensaio, não me preocuparei em relacionar as questôes identitárias de grupo inerentes aos modernistas, embora elas tangenciem minhas pesquisas em outros momentos.

Uma das marcas mais insistentes na palavra autobiográfica é a presença do mito de Narciso formando o ato e a predisposição autobiográfica ${ }^{5}$. Mais do que narcisismo tangenciando a patologia comportamental e psíquica, os textos autobiográficos espelham um modo de o homem compreender-se diante de seus mistérios. Os mitos servem a este propósito, isto é, para mostrar ao homem o que ele é e de que é feito. É esta preocupação que move meu olhar sobre a poesia e sobre as autobiografias. Contudo, não tenho certeza se essa perspectiva que adoto é a melhor ou a mais indicada para se trabalhar com poesia, isto é, a fim de buscar entendê-la, em um movimento cultural maior, mediada pelo imaginário ${ }^{6}$ e a partir daí fazer leituras em que pesem reatualizaçóes de mitos, a exemplo do que preconizava Gilbert Durand; também não tenho cristalizada a ideia de que o poema não deve ser tratado assim de forma tão científica como usualmente se faz nos meios acadêmicos, desembaralhando seus aspectos formais, como pretendem as leituras fenomenológicas de Ingarden ou mesmo dos formalistas russos. Optei por adotar algumas ideias de Bachelard como forças motrizes ${ }^{7}$. Uma delas é o binômio ressonância e repercussão. Essas ideias implicam que o crítico seja prioritariamente um leitor, mas não uma entidade abstrata, na qual cabem inúmeras pessoas sem rosto definido.

De certa forma, o que proponho é a necessidade de assumir uma identidade pessoal diante do poema de outrem, e para falar sobre ele, o poema, é preciso assumir 
essa individualidade, dizendo-se, nomeando-se, usando-se como caixa de ressonância, para que o poema encontre condiçóes de ser e de dizer aquilo a que veio. Quer dizer, em meio a tantas preocupaçóes com a objetividade científica, assumo minha individualidade e a reafirmo na medida em que elejo como material temático as revivências do mito de Narciso, que se espargem pelas autobiografias e pelos poemas que se comportam de maneira semelhante, tornando-me caixa de ressonância para os textos, ao mesmo tempo em que me revejo tanto nos poemas quanto nas autobiografias, provocando a repercussão.

A questão do mito parece ser simples. Esta aparência, no entanto, se desfaz quando pensamos nas inúmeras definições para o mito, quer antropológicas, psicanalíticas, sociológicas etc ${ }^{8}$. Relativamente ao mito e suas inserçóes nas culturas humanas, Gilbert Durand observou que, no decurso do tempo, os mitos se rearticulam, engordam e emagrecem, de acordo com as premências do momento em que são reatualizados. Durand chamou esse processo de "bacia semântica". Não quero, aqui, analisar todas as seis etapas cronológicas irregulares, sobre as quais se baseia a teoria formulada pelo antropólogo. Mas elas são: escoamento, separação das águas, confluências, nome do rio, ordenamento das margens e meandros e deltas ${ }^{9}$. Interessante reparar que essa metáfora potamológica dá conta dos processos de re-atualizaçóes dos mitos. Diz Durand:

Não há mito inicial, puro [...]. Qualquer mito não é senão o conjunto de suas liçôes, poder-se-ia mesmo dizer de suas leituras [...] O mito decompóem-se em alguns mitemas indispensáveis que lhe conferem sincronicamente o sentido arquetípico, mas, diacronicamente, ele é apenas constituído pelas liçôes circunstanciadas por esse acolhimento, essa leitura muito particularizada [...] Há que sublinhar este paradoxo, em que a permanência só é conferida pelas variações. (DURAND, 1996, p. 155).

Seguindo a ideia da bacia potamológica de Durand, penso no mito de Narciso com as suas inúmeras possibilidades de releituras, com acréscimos e subtraçóes de mitemas que o formam neste imenso arco temporal ocidental. Como já salientei, tenho observado o mito tanto na poesia quanto nas autobiografias. Posso dizer, então, que estou impregnada dos motivos de Narciso, e é justamente com esse olhar direcionado ao mito que, para este ensaio, leio Augusto Meyer, poeta gaúcho dos anos revoltosos do Modernismo brasileiro, que se tornou conhecido como ensaísta e, como tal, tratou de reler o cancioneiro gaúcho, os simbolistas franceses, Simóes Lopes Neto, Machado de Assis. Sobre sua produção ensaística, Tânia Franco Carvalhal (CARVALHAL, 2002) defendia que ele tinha clara preferência por trabalhar com autores que transfiguram a realidade aparente para, a partir disso, indagar às profundezas o que se oculta naquilo que se vê. Nas suas leituras críticas, 
nota-se a investigação psicológica dos mais variados personagens, ou seja, havia sempre, em Augusto Meyer, uma tentativa de captar o ser subterrâneo que habita o interior das personagens. Talvez, por isso, tenha sido um dos melhores leitores de Machado de Assis. E tenha feito de si mesmo o palco preferencial desta investigação.

Sua poesia integra a produção dos "novos do Sul", grupo formado por poetas que aderiram em diferentes medidas às ideias do Modernismo ${ }^{10}$. Em Meyer, as questôes relativas à nacionalidade brasileira, uma das grandes discussões da época, não se fizeram presentes como palavra de ordem ou mesmo como curiosidade intelectual, ou ainda como artifício de escritor. Nele, a afirmação das raízes nacionais se articula com uma busca de autenticidade individual, a qual se expressa em uma vontade de entender a si mesmo como um homem situado no seu tempo e no seu espaço. Sua obra poética se estrutura no fluxo contínuo entre o presente e o passado; entretanto, convém frisar, o trânsito entre aquilo que já foi e o que ainda é não tem caráter saudosista, como faziam os poetas românticos. Ao contrário, percebe-se em sua poesia um desejo ardente em recuperar estados de ânimo anteriores para, daí sim, poder perscrutar-se no presente.

A exploração do eu acaba por construir um eulírico fraturado, conflituoso, angustiado. Então, nada a estranhar que o espelho passe a representar um motivo preferencial. Tanto pode ser um cristal claro, uma sanga de águas profundas, vidraças, fundo de poço, enfim, qualquer situação em que o eulírico possa se refletir, todos os objetos têm uma superfície refletora movente, fluida, instável, pois é nela que o eulírico deposita seu olhar autoinquisidor. As imagens que surgem são visceralmente marcadas pela inconstância e pelo paradoxo. Instala-se, dessa forma, um jogo ininterrupto entre ser e parecer, falso e verdadeiro, parecido e estranho. Daí, talvez, a insistência em vocábulos como "fantasma", "vulto", "sombra". Sua poesia vai atrás da personalidade íntegra que está fracionada. Por outro lado, o espelho, lugar onde se deveria dar a identificação, é justamente o espaço onde mais se aviva a distância entre o eu e o eu-outro.

Meyer busca aquilo que não se vê, mas se percebe. O eu não é apenas uma referência biográfica, é mais do que esta circunstância oriunda do dado real. Trata-se de uma entidade absolutamente apaixonante, porque dual, ou mesmo múltipla, e que permite ao leitor uma relaçáo especular ${ }^{11}$. É consequência natural, então, afirmar que sua poesia é reconhecidamente marcada pelo seu caráter autocontemplativo ${ }^{12}$. Há um grande número de peças em sua obra cujo tema orbita o mito de Narciso, ou melhor, são re-atualizações bastante curiosas, as quais, grosso modo, apresentam resultados de tratamentos peculiares sobre o tema do duplo. Assim acontece, por exemplo, com o poema "Espelho", de Giraluz, com "Retrato no açude", de Últimos poemas, entre outros. Para encaminhar minha proposta de leitura, vejamos o soneto a seguir: 


\section{SANGA FUNDA}

Vem ver esta sanga funda

Com remansos de água clara:

Lá embaixo o céu se aprofunda,

A nuvem passa e não para.

Numa cisma vagabunda,

Olhando-me cara a cara,

Quantas vezes me abismara:

Água clara... alma profunda...

E que estranho era o meu rosto

No momento em que o sol-posto

Punha uns longes na paisagem!

Aprendi a ser bem cedo

Segredo de algum segredo,

Imagem, sombra de imagem... ${ }^{13}$

A leitura tantas vezes repetida deste soneto sempre deixa sensaçóes profundas de uma certa melancolia, entre doçura e tristeza. Ao mesmo tempo, provoca em mim novas questóes para a releitura do mito de Narciso. No poema estão colocadas as situaçôes reconhecíveis do mito: a água funcionando como espelho, o ato de mirar-se, o encantamento com a imagem produzida. No entanto, há tantas marcas diferenciadas! O poema toma conta de meus pensamentos e me vejo na pele do eulírico olhando o fundo da sanga funda. Como quer Bachelard, o poema é meu. Eis uma paráfrase: alguém chama um outro alguém para ver uma determinada sanga funda cujas águas parecem ser claras; no fundo da água se projetam uma imagem do céu com uma nuvem em movimento. $\mathrm{O}$ eulírico observa que muitas vezes se sentira abismado por ter-se perdido em pensamentos olhando a água clara e a alma profunda. Nesses momentos, isto é, no fim de tarde, seu rosto era diferente. Conclui que desde cedo aprendeu ser segredo de algum segredo, ser imagem de uma imagem.

A simplicidade vocabular induz ao equívoco de ler o poema rapidamente e nele não perceber suas mais profundas nuances e as imagens fortes que o sustentam. De aspecto formal inserido na tradição, isto é, o soneto, o poema é construído em redondilhas maiores, subvertendo o decassílabo sáfico, ou mesmo os alexandrinos de aspecto parnasiano, que o livro de 1922, Alguns poemas, sugere ao apontar para um ambiente 
parnaso-simbolista, ainda antes de sua adesão ao Modernismo paulista ${ }^{14}$. A primeira leitura já deixa perceber as rimas "abab" para os quartetos e "ccd - eed" para os tercetos, compondo uma certa rigidez estrutural que a fluidez da imagem do primeiro quarteto nega, funcionando como contraponto. Referendando o último verso (sombra de imagem), o texto se apresenta sob a chancela de uma forma clássica (o soneto) com o objetivo de falar intimamente de outra imagem, esta bastante diversa daquela aparente. No entanto, isto ainda não diz muito do poema.

O sistema de oposição que o poema encerra, tanto do ponto de vista formal quanto de significação, pode ser bem observado no verso 8: água clara... alma profunda... Parece que este verso, assim tão simples, encerra a profundidade significativa do poema, isto é, a imagem mais forte e mais vibrátil produzida pelo texto, ainda que o todo tendenciosamente se aproxime de uma estatização da imagem - como pareceria ao primeiro contato com o "mito original", em o movimento do decalque depende de maneira absoluta do original.

No poema de Meyer, o decalque tem vida própria, pois a profundidade da imagem acompanha a profundeza da alma daquele que se vê. Do ponto de vista formal, especificamente do verso, este se apresenta em dois hemistíquios, cada qual constituído por um substantivo e um adjetivo; há, no entanto, dois sintagmas nucleares que condicionam o verso e se espalham para todo o poema. Refiro-me à água e alma. Ambos estão juntos, porque no mesmo verso, e separados, porque em hemistíquios diferentes. Não é mera curiosidade! A água, arquétipo responsável por um número quase infinito de significaçóes míticas, e fundamental para o mito de Narciso, mantém relaçóes de contiguidade com a alma que, por sua vez, tem um campo de significaçáo muito abrangente. Um de seus símbolos mais frequentes, embora não o único, é o sopro e/ou a ave, que liga a alma ao elemento cósmico do $\mathrm{ar}^{15}$. O poema, desde seus versos iniciais, já introduziu o arquétipo do ar, ao lado do arquétipo da água; os vocábulos sanga, água, céu, nuvem, que compóem o primeiro quarteto, fundem a imagem, amalgamando-se nas suas diferenças espaciais. O céu está embaixo e a nuvem passeia nas águas. No entanto, diz Lurker a respeito da simbologia da alma: “[...] na psicologia profunda a água escura, insondável, é símbolo do inconsciente; o estado da água pode indicar o próprio sentimento da alma” (LURKER, 2003, p. 7). Parece que aqui o poema dá um nó, porque o verso 8 fala de água clara e não de água escura, como menciona o Dicionário de símbolos! Mas novamente o próprio poema e sua releitura incansável me conduzem a uma compreensão melhor: o verso 2 - com remansos de água clara - ajuda a compreender que se trata sim de água simbolicamente ligada às atividades do inconsciente e, por extensão, da alma. Remanso é cessação de movimento, é paz e tranquilidade; 
a sanga funda, e se funda é escura, tem remansos de água clara, mas não é remanso e tampouco clara.

A partir do primeiro quarteto, que une o alto ao baixo, o claro ao escuro, enfim, os diferentes, o poema é todo ele montado sobre a dicotomia do ser versus parecer, ou seria melhor: ser e parecer. O último terceto corrobora: o segredo é de um outro segredo, a imagem é sombra da imagem.

Retornando, então, ao verso 8 , acompanham os substantivos os dois adjetivos: clara e profunda. Em ambos também se percebe a oposição entre os seus termos de significação; no entanto, a antítese se perde porque as diferenças estão unidas para uma nova significação que farei referência mais adiante.

Sobre o mito de Narciso, base argumentativa para minha leitura, porquanto se trata de uma reatualização, é sempre bom lembrá-lo: apesar de ser um mito bastante conhecido, inclusive por causa das banalizações que vem sofrendo nas artes de consumo imediato, no ambiente literário sabe-se que foi inaugurado em Metamorfoses, do poeta latino Ovídio. No poema, o episódio relata a pequena e malfadada história do jovem efebo. Narciso, fruto da união forçada de Céfiso (deus-rio) com a ninfa Liríope, nasceu com extrema beleza, o que deixou sua mãe muito preocupada com seu destino, levando-a a consultar o adivinho Tirésias, que, perguntado sobre a vida do rapaz, responde que ele viverá muito se não se conhecer. Narciso segue, então, solitariamente. Ocorre que a ninfa Eco apaixona-se perdidamente por ele e o segue de longe em suas caçadas, mas é incapaz de pronunciar o nome do amado porque ela náo possui voz própria — só pode repetir as últimas palavras pronunciadas por Narciso. A ninfa foi castigada por Hera, esposa de Zeus, porque a jovem, com sua tagarelice, distraía a deusa enquanto Zeus fazia suas conquistas amorosas de outras ninfas. Ao descobrir o estratagema, a deusa a castiga, condenando-a a só repetir as últimas sílabas das palavras que ouvia. Por isso Eco não podia expressar seu amor por Narciso. Um dia, porém, o rapaz percebe que alguém, uma jovem, o segue e repete suas últimas palavras. Chama-a e pergunta por que ela o evita. Ao tentar responder, Eco apenas consegue repetir as palavras do amado e, desesperada por não conseguir se fazer entender, abraça-o e é rejeitada. Narciso lhe diz: "Para longe com seus braços, eu prefiro morrer a deixar que você me toque". Sendo rejeitada, a moça refugia-se nos bosques e montanhas e passa a morar sozinha até que, sofrendo as torturas do amor rejeitado, definha e se transforma em pedra, ficando somente o lamento de sua voz que repete as sílabas finais das palavras.

As outras ninfas também tentaram se aproximar do rapaz e foram repelidas, por isso invocaram a Justiça, pedindo a Nêmesis que as vingassem: "que também ele 
possa amar e jamais possuir o objeto de seu amor". Atendendo aos pedidos, depois de uma caçada, a deusa conduz Narciso a um recanto no qual, ao sentir sede, ele se inclina sobre uma fonte de águas cristalinas, a fonte Téspias, mas fica encantado com a imagem que aí vê refletida, pela qual se apaixona. Resolve então não se afastar da fonte, sempre buscando um contato com a imagem adorada. Não mais se alimenta e começa a definhar. Mesmo sabendo que se tratava de sua própria imagem refletida nas águas, morre perdidamente apaixonado por si mesmo sem jamais conseguir tocar-se. No lugar onde jazeu nasceu uma linda flor de poderes inebriantes que recebeu o nome de narciso.

Originalmente, todo mito encerra uma aprendizagem, e este ilustra o poder de Nêmesis que restabelece a justiça universal. Narciso foi punido por ter desejado subtrair-se à lei comum e por ter se recusado a amar alguém.

Augusto Meyer, ao escrever "Sanga funda", recupera alguns mitemas, reforçando-os a ponto de fazer o poema gravitar sobre eles, relegando os demais a um grau de esquecimento. Nesta reatualização, mitemas importantes como Eco e as relaçôes de amor imprescindíveis para a continuidade da espécie são deixadas de lado pelo poeta. $\mathrm{O}$ que importa é a interiorização do sujeito. Tudo o que é externo precisa ser interiorizado para ser melhor percebido. A sanga, pequeno regato que seca facilmente, passa a ser funda, isto é, qualidade do profundo, portanto basto de águas. Apesar de profundas, suas águas parecem ser claras, tão claras que no seu fundo se deixam ver o céu e a nuvem em movimento. Mas como pode uma fundura tamanha revelar uma imagem tão etérea? Mais do que um paradoxo, trata-se de uma representação do estado de ânimo do eulírico, ou já estaria antecipado no início do soneto a resposta-aprendizagem do último terceto? Meu estranhamento... O soneto faz afirmaçóes um tanto vagas, porque cheio de reticências; e, no entanto, eu leitora faço perguntas... como quer Bachelard, e novamente repito: o poema é meu!

A relação especular toma conta do texto, mas um espéculo que não reproduz o idêntico, como previa o "mito original". O eulírico também sofre de estranhamento. $\mathrm{O}$ primeiro terceto revela a diferença entre o original e o decalque, entre aquele que vê e aquele que é visto, entre o da superfície e o da profundeza. Mas o momento do sol posto delineia melhor a imagem e faz intuir a compreensão dela, novamente aparentando um paradoxo. O pôr-do-sol é extremamente significativo. Segundo Manfred Lurker, "o pôr-do-sol e a diminuição de sua trajetória, que se inicia no solstício de verão, são símbolos da morte, da desgraça e da descida ao Hades” (LURKER, 2003, p. 686). Contudo, na sequência das simbologias ligadas ao sol, há o motivo da devoração do sol por um dragáo, o que remete à ideia de ressurgimento. "Assim, a quase totalidade da simbologia do sol baseia-se na ideia de que a morte do sol é o processo de nascimento 
para uma nova vida" (LURKER, 2003, p. 686). O entendimento do "segredo", concretizado desde o início do poema na reprodução especular da autoimagem projetada nas águas claras da sanga funda, se faz neste terceto, isto é, no momento da quase escuridão surge de forma epifânica a compreensão da existência e seu modo de ser - a aparência que se relaciona em contraponto à essência.

Retornando à ideia de sistema de oposição entre aparência e essência, gostaria de salientar que o soneto, por si só um sistema de oposição assimétrico, é construído sobre esta base de compreensão da própria vida, isto é, segredo de algum segredo. Como em um labirinto de ideias, os dois últimos versos dão conta desta aprendizagem: a imagem, sombra de imagem implica um movimento centrípeto que, ao adentrar a interioridade do sujeito, lembra uma construção em abismo, aprofundando cada vez mais a essência do sujeito, pois a imagem não é apenas uma imagem, é uma sombra de imagem que se desvanece até perder seus contornos mais nítidos quando na superfície - e esta ideia parece estar referendada na aposiopese final.

Relendo novamente o poema, reparo que as aposiopeses, que tanto me chamaram a atenção, complementam três imagens: água clara, alma profunda e sombra de imagem. Elas estão sequenciadas, em uma espécie de gradação significativa que desvenda o poema e sua sabedoria, relacionando esta sabedoria com a aprendizagem preconizada pelos mitos. No momento inicial de minha leitura, fiz algumas consideraçóes sobre o verso 8, o qual é constituído pelas duas primeiras expressões aqui mencionadas. Já a terceira compóe o último verso. As duas primeiras parecem antíteses entre si (água clara versus alma profunda), porque seus sintagmas parecem se opor - água e alma. No entanto, observando mais atentamente, entendi que a água e o ar, elementos cosmogônicos simbolizados na sanga e no céu, estavam unidos de forma intrínseca. Bem, a terceira expressão, isto é, imagem, sombra de imagem..., que fecha o poema, é também o complemento da aprendizagem anunciada no verso 12 (Aprendi).

Sombra de imagem. Ainda fico perplexa com a força desta imagem! Em princípio, a expressão é uma redundância, porque a imagem é a representação mental ou plástica de um objeto em sua ausência; a sombra é o espaço sem luz. Em ambas, a marca é a ausência; na primeira é a ausência do objeto, na segunda é a ausência da luz. Certamente corrobora a ideia de algo escondido e, portanto, confidencial, íntimo, interno (conforme o verso 13). Só para lembrar: o poema inicia com o imperativo - Vem ver - enunciado pelo eulírico a chamar alguém que só será melhor evidenciado no pronome possessivo em primeira pessoa do verso 9 (e que estranho era o meu rosto). Trata-se, é claro, de um outro alguém interno, o simesmo dos gregos ${ }^{16}$. Além disso, o decalque é representado por um "rosto", elemento simbólico ligado à revelação de si. Chevalier 
\& Gheerbrant dizem que o rosto "é um desvendamento, incompleto e passageiro, da pessoa [...] ninguém jamais viu seu próprio rosto diretamente; só é possível conhecê-lo através de um espelho ou de uma miragem [...] é o eu íntimo parcialmente desnudado, infinitamente mais revelador [...] O rosto, símbolo do mistério, é como uma "porta para o invisível”, cuja chave se perdeu..." (CHEVALIER \& GHEERBRANT, 1997, p. 790:791).

A leitura mais detalhada deste soneto me encaminha para um outro poema, de teor igual. Retirado de seu último livro, a peça "Retrato no açude", também é construído a partir da reatualização do mito de Narciso, com pequenos diferenciais em relação à "Sanga funda". Transcrevo o poema:

\section{RETRATO NO AÇUDE}

1 Ergue-se um vago véu

2 De neblina e solitude.

3 Cada vez mais alto, o céu

4 Profundo caiu no açude.

5 Que silêncio de horizonte!

6 Chegou a hora mais grave.

7 Nem choro de sanga ou fonte,

8 Nem sussurro, voo de ave.

9 Só um arrepio de brisa

10 De leve encrespa a água lisa.

11 No pálido céu vidrado

12 Procuro-me, e lá no fundo

13 Há um fantasma debruçado

14 Para os lados do outro mundo.

15 Em si mesmo dividido,

16 Fantasma perdido e achado,

17 És reflexo refletido,

18 Em teus olhos retratado.

19 Leio na face que eu vejo

20 Para o alto debruçada:

21 Sou tão próximo e distante! 
23 Não turves com teu desejo

24 A paz desta água parada! ${ }^{17}$

Trata-se de obra da maturidade, na qual se percebe um retorno dos temas primeiros, bem como de retomada de certos preceitos formais. Últimos poemas, livro de onde retirei esta peça, data de 1950 a 1955, momento em que a poesia brasileira reescreve preceitos parnasianos. Assim se dá com poetas crescidos no Modernismo, a exemplo de Drummond, Bandeira, Murilo Mendes e Cecília Meireles (se bem que ela nunca abandonou seus traços parnaso-simbolistas).

Um poema, como se vê, construído com redondilha maior. É interessante pensar sobre esta questão, pois a redondilha é o metro preferencial dos poetas populares, tanto do Nordeste brasileiro quanto das cantigas de roda e da poesia oral gaúcha, as quais, especialmente, Augusto se dedicou a compilar, daí ter publicado Cancioneiro guasca. É metro popular porque traz forte apelo sonoro, o que facilita sua fixação ${ }^{18}$. Contrariamente à singeleza formal, é um poema muito denso.

Ainda pensando nos aspectos formais, gostaria de anotar algumas características que o distinguem. Ele é composto de seis estrofes, das quais as duas primeiras, a terceira e a quarta são rigorosamente construídas em quartetos; a terceira é um dístico e a sexta e última estrofe é uma sextilha. Estas estrofes, aparentemente disponibilizadas de forma simples, obedecem a um esquema prévio bastante complexo. Só para não esquecer: o poema anterior também apresenta uma aparência de simplicidade, simplicidade esta que incide sobre o vocabulário retirado do cotidiano, e eis um dos paradoxos bem ao gosto do poeta, cuja técnica utilizada revela que a aparência simples esconde uma essência densa, tanto do ponto de vista formal quanto do semântico.

Retornando a "Retrato no açude", a montagem estrófica denuncia e antecipa aquilo de que o poema irá "falar". Tento explicar melhor: são vinte e quatro versos heptassílabos divididos quase simetricamente; o "quase" fica por conta da última estrofe, uma sextilha, cujos versos expressam a soma do quarteto e do dístico. A ocorrência, portanto, de números que conformam o poema é bastante expressiva. Observando-o graficamente, vejo que ele se divide em dois blocos semânticos que se colocam um frente ao outro em explícita forma especular. Os quartetos - estrofes 1, 2, 4 e $5-$ são mediados pelo dístico, que parece funcionar como um divisor. Não à toa, o dístico faz uma passagem entre o primeiro bloco e o segundo: Só um arrepio de brisa / De leve encrespa a água lisa (versos 9 e 10). A terceira parte é a sextilha que fecha o poema, e nela se encontra outro tipo de expressão, que não as descriçôes contidas nos quartetos. 
Numericamente, esta estrofe reflete a soma do quarteto com o dístico, conforme apontado antes, e o número 6 é múltiplo de 2 , número base para a formação do quarteto e do dístico. Mas, a despeito destas consideraçóes, gostaria de ainda recorrer aos números para pensar o aspecto formal de maneira mais incisiva. Na poesia de Augusto Meyer, como na de vários contemporâneos seus, sente-se algo de barroco que lhe forma. $\mathrm{O}$ paradoxo, já apontado antes, é uma das expressóes de origem barroca, mas também a continuidade do paradoxo, isto é, o oximoro. Parece-me, se não estou exagerando, que o sistema estrófico aqui proposto pelo poeta corresponde a um "sentido" de oximoro, porque de duas metades, cujos assuntos são diversos, resta uma terceira que "resume" as posiçóes paradoxais. Tentarei me explicar melhor.

A sextilha é introduzida pelo verbo "ler" declinado na primeira pessoa do indicativo presente - leio - complementado, no mesmo verso 19, pelo verbo "ver", também na primeira pessoa - vejo - e verbo "ser" - sou - verso 21. Nesta última estrofe o eulírico assume o discurso enfaticamente: eu leio, eu vejo, eu sou. A implicação do uso destes verbos é imensa, porque em ambos está presente o olho, elemento por demais expressivo que conjuga, entre outras coisas, o conhecimento, a revelação epifânica etc., que culmina na caracterização mais íntima e essencial expressa pelo verbo "ser". A significação destes verbos, colocados justamente nesta gradação, reflete o processo de autorreconhecimento, como Narciso ao debruçar-se sobre as águas cristalinas da fonte Téspia. Não por mera coincidência, a estrofe é dividida, sob este aspecto, em dois momentos internos, os versos 19, 20 e 21, nos quais os verbos são conjugados na primeira pessoa, e os versos 22, 23 e 24, em que o verbo passa para o imperativo e assume a segunda pessoa do singular - aceita (verso 22), não turves (verso 23). Trata-se, enfim, de ler, de ver e de ser o simesmo em outro contexto não usual. Estes verbos finais do poema são encarregados de expressar a autoimagem profunda antevista no segundo bloco de quartetos que compóem a segunda parte do poema, segundo eu mesma postulei acima.

Entretanto, as partes estão integradas. Lembrando que poesia é revelação, como queria Octavio Paz, a sextilha recupera e explicita o verso 6, do segundo quarteto: Chegou a hora mais grave. A hora mais grave é aquela em que a vida se abre em revelação. Tal revelação comparece no verso 21: Sou tão próximo e distante! Eis novamente o paradoxo: "próximo" e "distante" são, como é óbvio observar, sintagmas de sentidos contrários, mas em Meyer eles estão em sinal de adição pela conjunção coordenada aditiva "e". O mesmo procedimento se encontra entre os versos 27 e 12. Não turves com teu desejo (verso 27) coloca o problema angustiante do autoenamoramento presente como mitema essencial do mito de narciso. Certamente o imperativo negativo garante a eficácia e o controle do desejo de tocar a água para, com o tato, conhecer o outro. 
Tal situação se contrapóe àquela em relação ao que diz o verso 12: Procuro-me. O verbo "procurar" implica desejo de encontrar alguma coisa, determinação de alcançar algo escondido. Ou seja, no início a ordem é o desejo da procura; no fim, a recusa em continuar a vasculhar. É impossível não ver aqui novos motivos no mito!

A aproximação destes contrários (próximo e distante) já foi antevista nos quartetos e agora, depois de ter perscrutado o final, volto-me para o início, isto é, as duas metades simétricas compostas por dois quartetos e um verso do dístico. Nelas, há uma espécie de gradação que vai da observação do cosmos (dois primeiros quartetos) até à questáo ontológica do eulírico (dois últimos quartetos). Para o primeiro bloco, é preciso observar a junção entre o alto e o baixo, o ar e a água, tal como apontei na análise do soneto "Sanga funda". Quer dizer, o motivo se repete. A beleza do verso por si só já vale o poema: Cada vez mais alto, o céu / Profundo caiu no açude. Aqui não se trata de sanga, como no soneto, mas de água que recebe o ar e que guarda profundezas na escuridão de suas águas. $\mathrm{O}$ momento é propício à introspecção, pois desce um véu permeado de neblina (anoto aqui o pleonasmo inteligente e poético!) e solitude. O ambiente se compóe como no mito, isto é, a natureza se prepara e ajuda na composição para o personagem e seu destino ${ }^{19}$. A queda do alto para o baixo, do céu para a água, encaminha a solidão como momento de ensimesmamento. O silêncio daí decorrente também comparece em vários poetas que costumam indagar a condição humana ${ }^{20}$.

Em Meyer, a própria natureza se cala para que a revelação comece. Nem a sanga, nem a fonte (água), nem voo de ave (ar) fazem presença para embaçar a hora mais grave. Sobre esta expressão que compóe o verso 6, de aparência inofensiva e solto sem grandes consequências (sintaticamente, nem é composto de verbo), gostaria de mencionar que se trata de um eufemismo para a hora da morte, e que parece ser a razáo mesma do poema. A revelação, à qual antes fiz referência, aqui se coloca como a culminância de uma vida que, finalmente, se reconhece. A hora da morte, como a hora mais grave, remete também ao contexto pessoal do poeta. O livro Últimos Poemas está repleto de elegias... ademais, os versos 13 e 14 igualmente configuram-se como prenúncio da morte: "Há um fantasma debruçado / Para os lados do outro mundo"(grifos meus), reiterando esta ideia.

O dístico, que divide simetricamente as duas primeiras partes do poema, introduz com muita leveza a dúvida existencial que irá compor os dois últimos quartetos. A singeleza da ação, notadamente através dos vocábulos arrepio, brisa e leve encrespa, contrapóe-se ao olhar perscrutador do eulírico, que se assume apenas no verso 12 . A força da ação dos quartetos subsequentes realiza o ato nuclear do mito de Narciso, sobre o qual o poema referenda como mitema essencial. Entretanto, esta reatualização 
subverte alguns elementos oriundos do "mito original", bem como de outras realizaçóes do próprio poeta. Nesta, não há mais a sanga, fundamental no soneto analisado ${ }^{21}$; não há a fonte de águas cristalinas, originalmente presente na narrativa do mito, já que o açude, pela sua própria profundidade, tem águas escuras; não há Eco, marcada no poema como ausência no verso 8, e sua ausência é sentida inclusive pela metonímia expressa em nemsussurro. Apenas o ar, já baixo, e portanto brisa (o ar alto é ventoso), comparece para dar um leve movimento ao espelho quase estático das águas do açude.

Os dois últimos quartetos, então, encerram a ação nuclear do poema, isto é, procurar-se na imagem que se reflete nas águas (quase) paradas do açude. Não se trata apenas de procurar, mas de procurar-se como ato reflexivo, apaixonante, angustiante, maravilhoso. Eis o mitema mais alardeado do mito, a visão moderna de olhar-se em paixão e angústia, porque a divisão interna a que o eulírico se submete é uma divisão em que cada parte do dividendo também se divide, como em uma construção em abismo em direção à interioridade do sujeito. A densidade do poema alcança, aqui, um patamar inusitado. O eulírico encontra um fantasma que do fundo das águas escuras observa sua imagem no eu que o produz. Trata-se de uma inversão nos reflexos normalmente atribuídos aos espelhos. É do fundo do espelho que a imagem do original surge. A aparência é subvertida pela essência. Na sequência do poema, o ato reflexivo do eulírico culmina nos verbos ler, ver e ser, já apontados anteriormente. Mas gostaria de observar que o eulírico não se vê nos olhos, e sim na face. Esta é também "símbolo do próprio ser de Deus ou de uma pessoa humana, da qual ela é a manifestaçáo" (CHEVALIER\&GHEERBRANT, 1987, p. 415). E, quando iluminada, refere-se ao conhecimento da divindade; no poema, a face está debruçada para o alto (verso 20), lugar de origem das primeiras observaçôes do eulírico - o primeiro quarteto - ergue-se, céu. Ainda na continuidade, anoto que a expressão no fundo (verso 12) que provoca a rima cruzada com mundo (verso 14), implica a profundidade estelar anunciada no primeiro quarteto, como também a profundidade do poço sem fundo do açude e a profundidade dos olhos que se miram em imagens sobre imagens (como posto no soneto). De todos os modos, a imensidão estelar refletida nas águas do açude e o olhar infinito que se olha encaminham o eulírico a um reconhecimento de si como o outro, isto é, uma imagem fantasmagórica que, associada ao verso 14 , remete ao contexto de finitude, de morte.

No entanto, o personagem do fantasma, tal qual o reflexo do efebo da lenda, quase se torna figura independente daquele que a criou com o simples reflexo. No poema, a imagem é por si só dividida (e não o original), porque é perdida e achada. Lembra bem o drama de Narciso da lenda: quando ele toca a figura que vê no mesmo plano da água cristalina da fonte Téspia, a imagem se dissipa; aqui se dá o mesmo, com 
algumas alteraçóes, porque o movimento é invertido: primeiro se perde, depois se acha (no mito, primeiro se acha para depois se perder). A conclusão de tal inversão e de movimento táo íntimo é uma retomada do que o poeta já escrevera em textos de teor semelhante, isto é, És reflexo refletido (verso 17) é uma outra forma de dizer Imagem, sombra de imagem (do soneto "Sanga funda").

Retorno, finalmente, ao todo do poema, sem esquecer do soneto "Sanga Funda", para fazer algumas observaçóes que me parecem necessárias, ou que pelo menos me ajudam a reler com um sabor mais intenso de identificaçóes e encantamentos a poesia deste gaúcho tão singular. $\mathrm{O}$ mito de narciso é composto de alguns mitemas que fornecem uma identidade à fábula. Em "Sanga funda" quero referir certos objetos e açôes, ou seja, uma água para a vidência do reflexo, um desejo de buscar-se, um reflexo que o eulírico Narciso chama de fantasma, uma evidência da cisão entre o decalque e o original, um olho (indireto) que abre o conhecimento. Entretanto, Meyer introduz no meio aquoso típico da narrativa mítica o elemento aéreo, renovando e reatualizando o mito, como ensina Durand. Da mesma forma que procede em "Sanga Funda", o poeta chega à água do açude (no soneto, da sanga), onde se dá a revelação especular, através do ar em seus desdobramentos (os elementos simbólicos que "representam" o arquétipo do ar). Compóem estes elementos simbólicos: véu, alto, céu, brisa, voo de ave, nuvem. Em ambos poemas, há um movimento de queda (as coisas do céu caem dentro da água) e de ascensão (as imagens que estão dentro das águas profundas são imagens voltadas para o céu). E, como ensina Bachelard, desejo obstinado de ascender é típico do homem sonhador aéreo. Para referendar, a lembrança de um último verso: Para o alto debruçada.

\section{NOTAS}

\section{$\sin 2$}

1 Trata-se, em suma, de uma tripla identidade contratual: o nome do autor, explicitado na capa, deve ser exatamente o mesmo do narrador e do protagonista.

2 A bibliografia sobre o assunto já é significativa, ainda que alguns autores façam apenas modificaçóes na nomenclatura utilizada para referir questóes relativas à palavra autobiográfica. Sobre o termo "autoficção", tão em moda hoje em dia, ver o interessante ensaio de BOLAÑOS, Aimée. Imaginário do eu nas escrituras transculturais: propostas do pensamento quebequense atual. In: BERND, Zilá (Org.). Imaginários coletivos e mobilidades (trans)culturais. Porto Alegre: Nova Prova, 2008.

3 Cf. LEJEUNE, Philippe. Le pacte autobiographique. Paris: Seuil, 1975.

4 Gostaria de explicar que tenho realizado pesquisas muito interessantes sobre as autobiografias dos poetas modernistas, observando-as como uma espécie de "o outro" da ficção, especialmente quando a referência para ficção seja a poesia. Daí meu interesse em tangenciar algumas questôes relativas 
ao gênero autobiográfico, do qual possa retirar o tema do mito de Narciso compondo boa parte da poesia desses poetas.

5 Ver ROCHA, Clara Crabbée. Máscaras de Narciso. Coimbra: Almedina, 1992. E SOUZA, Raquel. Boitempo: a poesia autobiográfica em Drummond. Rio Grande: Ed. FURG, 2002.

6 Refiro-me às reatualizaçôes de mitos conforme DURAND, Gilbert. Perenidade, derivaçôes e desgaste dos mitos. In: Campos do imaginário. Lisboa: Instituto Piaget, 1996.

7 Tenho usado com muita frequência suas ideias sobre a poesia, especialmente nos livros aos quais ele se dedicou a uma fenomenologia baseada na cosmogonia através dos quatro elementos: fogo, água, ar e terra.

8 Estas referências também são inúmeras, mas tenho aproveitado estudos relativos aos mitos de CAMPBELL, Joseph (Org.) Mitos, sonhos e religião. Rio de Janeiro: Ediouro, 2001; ELIADE, Mircea. Aspectos do mito. Lisboa: Ediçóes 70, s/d. RUTHVEN, K.K. O mito. São Paulo: Perspectiva, 1997; BIERLEIN, J. F. Mitos paralelos. Rio de Janeiro: Ediouro, 2004; além dos já clássicos dicionários de mitos e mitologias, entre outros textos.

9 Sobre o assunto, ver DURAND, Gilberto. Perenidade, derivaçôes e desgaste do mito. In: Campos do imaginário. Lisboa: Instituto Piaget, 1996.

10 A título de lembrança, são eles: Theodomiro Tostes, Ruy Cirne Lima, Vargas Netto, Paulo de Gouveia, Athos Damasceno Ferreira, Ernani Fornari e Raul Bopp.

11 Augusto Meyer, ao longo de sua produçáo ficcional, institui para si mesmo dois personagens que o representam de maneira diversa: Bilu, de caráter irreverente, como queria o Modernismo; e Aug, sujeito austero e preocupado com as coisas da vida. Ambos funcionam como imagens especulares do autor, assumindo, cada uma, faces diversas.

12 Gostaria de observar que o caráter dual do eulírico em Augusto Meyer repercute intensamente como princípio dominante na estruturação de sua obra. Os pares opositivos que fundam a consciência do eulírico se espargem também pela forma através da qual ele se expressa. Ainda neste sentido, aponto que sua poesia apresenta outro tema, que não este de que trato no momento. Refiro-me à metapoesia como parte integrante de reatualizaçáo do mito de Narciso, e que por questôes de espaço e de oportunidade, não farei referências neste ensaio.

$13 \mathrm{O}$ poema encontra-se em: MEYER, Augusto. Alguns poemas. In: . Poesias - 1922-1955. Rio de Janeiro: Livraria São José Editora, 1957.

14 Segundo Tânia Franco Carvalhal, o poema, apesar de estar inserido no livro Alguns Poemas, de $1922-$ 1923, no volume Poesias, compilado pelo próprio autor, foi escrito mais tardiamente, em torno dos anos 50 e posteriormente, quando da edição de Poesias, foi lá inserido. Cf. CARVALHAL, Tânia Franco. Quanto mais vaga, mais viva. In: MEYER, Augusto. Melhores poemas de Augusto Meyer. São Paulo: Global, 2002.

15 Sobre os elementos arquetípicos da água e do ar, presentes na poesia de Augusto Meyer, ver dissertação de mestrado orientada por mim: RICHTER, Marcela Wanglon. Toda a gente lê no azul mais alto o seu destino: poesia e imaginário em Giraluz, de Augusto Meyer. Rio Grande: Universidade Federal do Rio Grande, 2007 (mimeo).

16 Tomo o termo aqui na acepção dada por VERNANT, Jean-Pierre. A morte nos olhos: figuração do outro na Grécia antiga - Ártemis e Gorgó. Rio de Janeiro: Jorge Zahar, 1991.

17 Poema retirado de MEYER, Augusto. Últimos poemas. In: ___. Poesias — 1922-1955. Rio de Janeiro: Livraria São José Editora, 1957.

18 Sobre o assunto, ver ALI, Manoel Said. Versificação portuguesa. São Paulo: Editora da Universidade de São Paulo, 1999. 
19 Bachelard, em estudo sobre a água, descerra questôes intrigantes para a recomposição de Narciso a partir de sua inserção na natureza. Ela, a natureza, compóe o cenário onde se dará a revelaçáo, e como cenário participa ativamente do processo no qual o protagonista busca sua imagem. Ver BACHELARD, Gaston: As águas claras, as águas primaveris e as águas correntes. As condiçōes objetivas do narcisismo. As águas amorosas. In: . A água e os sonhos. Trad. Antônio de Pádua Danesi. São Paulo: Martins Fontes, 2002.

20 Ver excelente estudo de DURAND, Gilbert. Psicanálise da neve. In: Campos do imaginário. Lisboa: Instituto Piaget, 1996.

21 É muito curioso reparar que o soneto "Sanga Funda" foi incluído no primeiro livro de Augusto Meyer, Alguns poemas, de 1922, por ele próprio quando fez a edição de suas poesias completas, em 1955, ano de Últimos poemas. Cf. CARVALHAL, Tânia Franco. Quanto mais vaga, mais viva. In: MEYER, Augusto. Melhores poemas de Augusto Meyer. Rio de Janeiro: Global, 2002.

\section{REFERÊNCIAS}

CARVALHAL, Tânia Franco. Quanto mais vaga, mais viva. In: MEYER, Augusto. Melhores poemas de Augusto Meyer. São Paulo: Global, 2002.

CHEVALIER\&GHEERBRANT. Dicionário de símbolos. Rio de Janeiro: José Olympio, 1997.

CUNHA, Antônio Geraldo da. Dicionário etimológico da Lingua Portuguesa. Rio de Janeiro: Lexicon Editora, 2007.

DURAND, Gilbert. Campos do imaginário. Lisboa: Instituto Piaget, 1996.

LEJEUNE, Philippe. El pacto autobiográfico: veinticinco años después. In: Autobiografia em España: un balance. Madri: Visor Libros, 2001.

LEJEUNE, Philippe. Le pacte autobiographique. Paris: Seuil, 1975.

LURKER, Manfred. Dicionário de símbolos. São Paulo: Martins Fontes, 2003.

MEYER, Augusto. Poesias. Rio de Janeiro: Livraria São José, 1957.

VERNANT, Jean-Pierre. A morte nos olhos: figuração do outro na Grécia antiga. Trad. Clóvis Marques. Rio de Janeiro: Jorge Zahar, 1991.

\section{Resumo}

Tomando como base argumentativa algumas questôes do gênero autobiográfico na perspectiva das teorias do imaginário, propostas pelo antropólogo Gilbert Durand, este ensaio busca realizar um estudo hermenêutico sobre dois poemas de Augusto Meyer. O tema que o circunda é o processo de reatualizaçáo do mito de Narciso presente na poesia modernista brasileira. Pretende-se observar os mecanismos de engorda e de emagrecimento relativos aos mitemas presentes nos poemas.

Palavras-chave: Gênero autobiográfico, Poesia modernista, Poesia e imaginário, Mito de Narciso. 


\section{Abstract}

Taking as argumentative base some questions of the autobiographies sort in the perspective of the theories of the Imaginary, by Gilbert Durand, this essay search to carry through a hermeneutic study on two poems of Augusto Meyer. The subject that surrounds it is the process of reverse speedupdate of the myth of narcissus presents in the Brazilian modernist poetry. It is intended to observe the mechanisms of fattening and thinning about mitemas in poems.

Keywords: Autobiographic genre; Modernist poetry; Poetry and imaginary; Myth of Narcissus.

SOUZA, Raquel. Uma leitura do mito de Narciso: as águas profundas de uma sanga gaúcha. Légua \& meia: Revista de literatura

Raquel Souza é professora associada do Programa de Pós-Graduação em Letras da FURG (Fundaçâo Universidade Federal do Rio Grande). Graduada em Letras pela FURG, mestre e doutora em Literatura Brasileira pela UFRGS (Universidade Federal do Rio Grande do Sul). Publicou, entre outros livros, Boitempo: autobiografia de Drummond (2002) e O canto de Lilita \& outros poemas (2008). 